(C)2018, Elsevier. Licensed under the Creative Commons Attribution-NonCommercialNoDerivatives 4.0 International http://creativecommons.org/about/downloads 


\title{
Caring for nature matters: a relational approach for understanding nature's contributions to human well-being
}

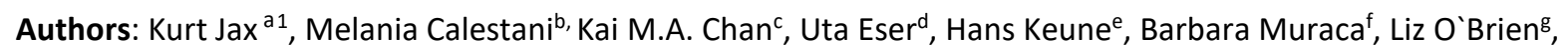
Thomas Potthast ${ }^{\text {h }}$, Lieske Voget-Kleschin ${ }^{i}$ Heidi Wittmer ${ }^{j}$

${ }^{\text {a }}$ Department of Conservation Biology, Helmholtz-Centre for Environmental Research-UFZ, D-04318 Leipzig, Germany

${ }^{\mathrm{b}}$ Faculty of Health, Social Care and Education, Kingston and St George's, University of London, London, SW17 ORE, UK

' Institute for Resources, Environment, and Sustainability, University of British Columbia, Vancouver, BC, Canada V6T $1 Z 4$

d Büro für Umweltethik, D-72072 Tübingen, Germany

${ }^{\mathrm{e}}$ Belgian Biodiversity Platform - Research Institute for Nature and Forest (INBO), B-1000 Brussels, Belgium \& Department of Primary and Interdisciplinary Care - Faculty of Medicine and Health Sciences - University of Antwerp B-2610

${ }^{f}$ School of History, Philosophy, and Religion, Oregon State University, Corvallis, OR 97331, USA

${ }^{\mathrm{g}}$ Centre for Ecosystems, Society and Biosecurity, Forest Research, Farnham, Surrey GU10 4LH, UK

${ }^{\mathrm{h}}$ International Centre for Ethics in the Sciences and Humanities, and Chair for Ethics, Theory, and History of the Life Sciences, University of Tübingen, D-72074 Tübingen, Germany

' Department of Philosophy, University of Kiel, D-24118 Kiel, Germany.

${ }^{j}$ Department of Environmental Politics, Helmholtz-Centre for Environmental Research-UFZ, D-04318 Leipzig, Germany

\begin{abstract}
Ecosystem services frameworks effectively assume that nature's contributions to human well-being derive from people receiving benefits from nature. At the same time, efforts (money, time, or energy) for conservation, restoration or stewardship are often considered costs to be minimized. But what if caring for nature is itself an essential component of human well-being? Taking up and developing the concept of relational values, we explore the idea that well-being cannot be reduced to the reception of benefits, and that instead much derives from positive agency including caring for nature. In this paper, we ask specifically, a) how can "care" be conceptualised with respect to nature, b) how does caring for nature matter both to protecting nature and to people's well-being, and c) what are the implications for research and practice?

We describe the theoretical background, drawing especially from (eco)feminist philosophy, and explore its (mostly) implicit uses in the conservation literature. Based on this analysis we propose a preliminary framework of caring for nature and discuss its potential to enrich the spectrum of moral
\end{abstract}

${ }^{1}$ Corresponding author: email: kurt.jax@ufz.de, phone: +49-341-2351648 
relations to/with nature. We explore both its consequences for environmental research and for the practice of conservation.

\section{Introduction}

The global environmental crisis has prompted not only research on scientific explanations and technical solutions but also on a deeper understanding of human-nature-relationships. In order to promote political action, endeavours such as Millennium Ecosystem Assessment, TEEB (The Economics of Ecosystems and Biodiversity) and the Intergovernmental Science-Policy Platform on Biodiversity and Ecosystem Services (IPBES) have demonstrated nature's importance for human wellbeing. Concepts like 'nature's benefits for people' or 'nature's contributions to people' (as IPBES frames it $\left[1^{* *}, 2^{* *}\right]$ ) emphasise nature's decisive role for the good life of humans. However, many share the intuition that nature is not merely a means to human ends, nor and end in itself. In fact, there appears to be a broader and richer set of human relations with nature, which transcends the distinction between instrumental and intrinsic values. This perspective does not only consider the question what nature does for people but also acknowledges a diverse set of other relationships with nature and the values associated with it. This relational perspective addresses the close fabric of human and non-human aspects of shared social-ecological systems [3: 63f, 4, 5] ${ }^{2}$.

Numerous concepts have been suggested to describe the relationship between humans and nature ${ }^{3}$. We here start from a value perspective. Values are 'conceptions of what is ultimately good, proper, or desirable in human life' [13: 1]. They play an important role in definitions of well-being [14, 15]; furthermore, social and cultural systems and differences, such as class, influence individual models and perceptions of what constitutes well-being. Traditionally, value(s) of nature are captured as either instrumental (i.e. a means to human ends) or intrinsic (i.e. a natural entity is valuable in itself, independent of human ends). Relational values, going beyond this distinction, express relations that are constitutive of a good life, i.e. a life worthy of a human being, in which not merely surviving, but flourishing can be achieved ${ }^{4}$.

In this paper, we draw on the concept of relational values to discuss what the attitude and practice of care can mean for both nature conservation and well-being. Relations of care with and for nature clearly cannot be framed in merely instrumental terms. Caring is not only an attitude of concern for the well-being of another, but also and foremost a practice $[18,19,20]$ that seeks to tend to another's needs (with or without benefit to oneself), be the other a human or a non-human entity. Care is a central element of human well-being [21] and agency [18] and fosters trust, social cohesion, and responsibility [19].

While care for nature has been mentioned as an important way of relating to nature, little systematic attention has been dedicated to it. Exceptions are inter aila given in ecofeminism, feminist ecological economics [22,23], as well as human geography and non-Western environmental philosophies (see below).

\footnotetext{
2 The combined works of nature and humans have, e.g., also been conceived as "cultural landscapes" [6], nature-culture-regimes [7, 8] or socionatures [9].

${ }^{3}$ E.g. psychologists have devised different scales to assess human beings' relationships, such as the Nature Relatedness scale [10], the Connectedness to Nature scale [11], or the Love and Care for Nature scale [12].

${ }^{4}$ In a broader sense, instrumental values are relational as well, as they refer to an instrumental relation [16]. However, by following more recent literature on relational values, we employ the concept here in a narrower sense to stress the specific relevance of non-instrumental relations with nature [see $\left.4,5^{* *}, 17\right]$. In the same line of argument, we set apart instrumental and relational values from intrinsic values [sometimes called inherent values, as in 4].
} 
In the following sections, we review the role that care can play for nature conservation and address critical questions on the application of the concept ${ }^{5}$. We then suggest a first framework of caring for nature and briefly address what care might imply for research and practice.

\section{Care concepts and how they have been applied in the context of human-nature relationships}

As highlighted by Buch [24: 279], 'care' connotes both affective concern (caring about) and practical action (caring for); this double meaning contributes to beliefs that caring actions are most naturally motivated by caring feelings $[25,26]$. Although caring about and caring for should be connected, practical priorities often shifts the emphasis to 'caring for'. However, the affective concern has important implications to legitimise meaningful actions.

\section{The concept of care (for nature) in feminist theories}

Feminist philosophers have introduced the concept of 'care ethics' to address moral considerations, such as taking responsibility for the needs of particular others, neglected by approaches that focus on justice (rights) or utility (preferences), [19]. Care ethics in general stresses the importance of emotions and empathy in the formation of moral judgments and principles that guide action; it considers actual relationships in their specific, contextual implications, and partiality [27]; it challenges the separation between the public and private sphere [19] and the Western liberal concept of the person as an autonomous individual, guided in the first instance by its rationality. Against this conception feminist care ethics employs a radically relational understanding of the self that focuses on the self as constituted by its relations to other beings [18].

Specifically with regard to human-nature relationships, feminist theories of care can:

a) foreground the role of empathy [28] and of emotions as drivers for nature conservation [29], for example in terms of feelings of connectedness or grief when "treasured aspects of the natural environment are lost" [30: 974];

b) focus on the irreplaceable qualities of particular ecosystems and landscapes and voice the unique, constituting relationships among their human and nonhuman inhabitants in a particular community, thus challenging reductive instrumental language, commodification, and compensation offers [31]. As such they offer a solid basis for the articulation and justification of non-instrumental relational values;

c) highlight the constituting role of (re)productive activities ${ }^{6}$ and 'sustaining services' $[33,32]$ and the mediation through which ecosystem potentials are mobilized by human agency and labour [34, 35, 36];

d) articulate the reciprocity of human-nature relationships (reciprocal restoration [30]; gift paradigm [31]) and the idea that a necessary condition to become care-givers is to acknowledge one's own condition as care-receivers (beneficiaries of care), i.e. of the fundamental reliance on constituting relations with the natural environment and with others [37].

\footnotetext{
${ }^{5}$ Our starting point is feminist care ethics, because we here found the most elaborate philosophical explorations on the concept of care.

${ }^{6}$ (Re)productivity refers to all creative (productive) activities that are exploited but not valued by capitalistic production, and includes ecological (regeneration of the soil, photosynthesis, absorption capacity etc.) as well as social processes (caring for children, for elderly or sick people, friendship), and their mediation (nourishing and cooking, storing seeds, healing, repairing, etc.) [31, 25].
} 


\section{Indigenous/traditional approaches}

The feminist perspective on care presents commonalities with perspectives that are critical of the Western paradigm as they are expressed for example in geography and anthropology [e.g. 38, 39]. Ideas of the person as embedded in and constituted by a web of relations both between humans and between humans and non-human entities is common in a number of indigenous and traditional (mostly) non-western narratives. Often, moralities among indigenous communities include good social relations with other human beings, and also with the natural world (land and sea), which is recognized as being alive; respect for and responsibility to the land is an important belief and a moral tie. Nature is often at the same time care-giver and care-receiver. This has been shown in case studies from North and South America [40, 41, 42*], Australia [40, 43, 44], New Zealand [42*] and African countries $[45,46]$.

Care is at the same time a fundamental attitude that shapes the self-understanding of persons and community - and thus also contributes to human well-being $[47,48,49]$ - and a set of practices that corroborates commonality and reciprocity between humans and with nonhumans. Especially in indigenous approaches, caring relations are often intimately connected to a spiritual dimension, which is paramount both for maintaining (or restoring) the personal identity of people and their idea of community, both with each other and the non-human world. Attitude and practice here often become inseparable (as different from e.g. some kinds of western stewardship concepts [55 and see below]).

\section{Environmental philosophical approaches}

Western environmental philosophy has discussed care under different headings. According to its founder, Arne Naess, "deep ecology" should aim at "extending care to humans and deepening care for non-humans", [cited in 50:, 449]. Likewise, Leopold's prominent "land ethic" [51] has been interpreted as an approach of caring for the land [e.g. 52: 63ff., 53]. Rolston [54] has introduced the concept of caring for nature with reference to the guiding role of religion in the formation of values.

The concept of "environmental stewardship" (also earth stewardship, ecosystem stewardship), can also refer to an attitude and practice of care for nature $[55,56 *, 20]$. While some scholars interpret stewardship in terms of (resource) management [e.g. 57], others conceive of stewardship as the broader set of human relationships with nature and as a morally grounded caring attitude and practice [58]. The concept of stewardship has also been used in (and partly is rooted in) religious and spiritual traditions, but not without some critique [55].

The idea that good relations with others, among them care, belong to good human life, is rooted also in one strain of western philosophical traditions, namely in virtue ethics. Going back to Aristotle's concept of eudaimonia, virtue ethics at least implicitly underlies some modern environmental philosophies and is more explicitly adopted by "environmental virtue ethics" [59, 60, see also 61$]^{7}$.

\section{Commonalities and unresolved questions in the diversity of concepts of care with respect to nature}

Most approaches of care towards nature share an understanding that deviates from the currently dominant western view of humans as autonomous individuals characterised by rationality as the foremost human attribute. In contrast, care-oriented approaches emphasise dependencies, reciprocity and the highly relational character of human life. The higher valuation of emotional bonds to (human and non-human) others implies a different understanding of how reason operates and a rejection of merely instrumental rationality.

\footnotetext{
${ }^{7}$ On the relations between care ethics and virtue ethics see [62].
} 
In terms of the entities for which a responsibility of caring may exist, the question of proximity emerges as an open question, e.g., with respect to a duty to care for domesticated animals but not for wild ones $[63,64]$.

When care as practice refers to the specific needs of single (such as individual organisms) or collective entities (like a forest or an 'ecosystem'), it remains unclear how those needs can be identified and met. Different cultural norms, traditions, and interests might lead to controversial interpretations across different social groups. What are the needs, e.g. of a forest or a river?

As with any other issue related to human-nature interactions, practices of care are also situated on a gradient between 'non-interference' and 'manipulating interventions'. For example, while caring for wilderness often implies an attitude of "letting nature take its course", caring for domesticated animals, whose survival depends on us, might require more active, even paternalistic, interventions. This is an important matter of controversy that needs to be addressed in processes of societal deliberation about different experiences and normative settings. A good example is the different understanding of the relation to resources in the Black Forest National Park in Germany: local residents claim that harvesting timber and collecting berries and mushrooms not only embodies an old traditional habit, but constitutes a practice of care. Accordingly, wasting nature's gifts would be considered careless. For many nature conservationists, instead, care would imply a non-interfering practice.

\section{Elements of a framework of caring for nature}

By broadening the spectrum of human-nature relationships beyond instrumental interactions, the concept of care can fructify the current conservation discourse in three ways.

First, a care perspective allows for additional modes of justification. It enables arguments that foreground emotional bonds between humans and nature which tend to be ignored in discourses based on instrumental reason only (for a critique of instrumental reason see [65]). Based on a more inclusive concept of reason that is not in opposition to emotions[66], this perspective accepts emotions, context, and concern for particular others as comprehensible reasons. Instead of being excluded from the moral discourse, caring feelings are considered as valuable complements and legitimate arguments. Moreover, it stresses the relational constitution of the self and challenges the reduction of relations to merely instrumental links.

Second, a care perspective complements existing ways of motivation. It adds a new quality to the debate that is neither utilitarian nor based on presumed moral rights of nature. A relational perspective regards humans as beings who fundamentally depend on others - and on nature, too. Such a self-image comes much closer to many people's personal experiences and intuitions than the dominant image of humans as autonomous rational beings and therefore may have stronger motivational force. Every person in at least some parts of their life experiences being cared for or caring for others. Accordingly, other-regarding attitudes and practices are fundamental constituents of human life. Against a narrow utilitarian perspective - as it is expressed in the figure of the Homo Oeconomicus - care appeals to empathy and altruism instead of drawing on self-interest only as a motive and driver for action. From a relational perspective, a caring relationship between humans and nature is intrinsically valuable and therefore desirable.

Third, a care perspective broadens the spectrum of conservation practices. Taking care into consideration shifts the focus of practical measures from the quality of the ecosystem to the quality of the interaction. A focus on care-directed interactions between humans and nature can complement science-based management measures with practices of care that are rooted in culture, tradition, religion, or personal relationships. Hence, it has the potential to integrate a diversity of languages and epistemic perspectives, such as for example indigenous and local knowledge.

Possible conservation practices rooted in care encompass: 
- Conservation and restoration practices: These comprise active care for the natural environment in its different forms (a) ecosystems, (b) species, (c) individual organisms, (d) 'country' or the land as a specific, located place of interactions;

- Practices of production: These comprise care-directed management of land-use systems (e.g., grazing, farming and gardening) that embodies and expresses concern for the land, soil, wildlife, future generations, etc.;

- Practices of consumption: This refers to caring by proxy, via purchases; e.g. consumers buying certified products or deliberately not buying or consuming certain products;

- Practices of participation: In contrast to the stakeholders-centered view that participation is rooted in participants' own interests, conceiving participation as a practice of care accommodates people that may participate out of genuinely altruist environmental concern.

Summing up, we discriminate between the following notions of care (see Table 1):

'Care' as a relational and context-sensitive argument that provides an additional mode of justification for conservation measures as a complement to justifications guided by universal rational principles.

'Care' as an action-orienting attitude rooted in a relational conception of the self that bears stronger motivational force. As a complement to the dominant model of humans as self-interested utility maximizers, care-based motivation links an individual's wellbeing to the well-being of (particular) others.

'Care' as a series of practices that are rooted in culture, religion or emotion as complements to merely science-based technical measures or management practices.

Table 1: A framework of care with regard to nature (see text)

\begin{tabular}{|l|l|l|}
\hline Notion of care & Focus on & Complement to \\
\hline $\begin{array}{l}\text { Mode of } \\
\text { Justification }\end{array}$ & $\begin{array}{l}\text { Particular others } \\
\text { Specific context } \\
\text { Emotional and relational arguments }\end{array}$ & $\begin{array}{l}\text { Instrumental rationality } \\
\text { Science-based and logical arguments }\end{array}$ \\
\hline $\begin{array}{l}\text { Motivational } \\
\text { force }\end{array}$ & $\begin{array}{l}\text { Intention and motivation } \\
\text { (Inter)subjective perspective } \\
\text { Relational self-conception }\end{array}$ & $\begin{array}{l}\text { Cause and effect } \\
\text { Objective data } \\
\text { Self-interests and utility maximization }\end{array}$ \\
\hline Practice & Culture, religion and/or emotion & $\begin{array}{l}\text { Science-based knowledge and } \\
\text { technology } \\
\text { (discrete) outcome of interaction }\end{array}$ \\
\hline
\end{tabular}




\section{Consequences for research and practice}

We suggest complementing rather than replacing utilitarian arguments for protecting nature with the concept of care. What the notion of care adds to the debate on the relation between humans and nature is summarized in table 1: arguments of justification (what do people care for, under what circumstances?), stronger motivational force (how and why do persons care?) and a stronger focus on practice (in what way, embedded in which broader practices?). Here we discuss what this implies for frameworks, for research, and for conservation practice.

\section{Complementing frameworks such as the ecosystem service cascade and IPBES}

Common frameworks such as the cascade model by Haines Young and Potschin [67] explain the relationship between nature and well-being as unidirectional: from ecosystems to benefits and values. The basic lines of the argument are utilitarian and reduce all types of relations to merely instrumental interests; non-instrumental relational values are neglected. Neither are practices conceptualised or derived from individual motivations. The IPBES Framework, especially through the initial work on multiple values [68], in principle acknowledges relational values as a distinct category in addition to intrinsic and instrumental values and provides a direct link from nature to well-being via relational values, without the need of a direct benefit to arise. This aspect is somewhat lost again in the later publications $\left[1^{* *}, 2\right]$ that focus on conceptualizing nature's 'benefits' as 'contributions' and lose the focus of direct relation between nature and society mediated by culture and practice. For these frameworks the link that care and thus a two-directional relationship can add is to include not only "what are people interested in receiving from nature" but also "what do people care for, what practices do they want to engage in to maintain or achieve what state of nature and how does this affect their well-being?"

\section{Consequences for research:}

With regard to research on human-nature relationships, the idea of care implies specific relations, challenging the idea of a commensurability of values [69]. It calls for interdisciplinary as well as pluralistic valuation approaches $[70,71]$ using multiple and mixed methods, such as plural, deliberative, and participatory multi-criteria valuation $(72,73]$, often linking qualitative and quantitative approaches ${ }^{8}$. Beyond this, in order to capture and adequately deal with relational values that are shared collectively and individually [74], research will have to go beyond valuing. Rather it needs to incorporate ideas of fairness, justice and make explicit shared meanings and responsibilities. Care, as an important subset of relations, provides a strong justification for such a new focus on relational values and an extension of methods connected to it. Open methodologies including deliberative evaluation $\left[75^{* *}, 76\right]$ using the notion of care - can serve as a useful entry point and allow people to express their relation to nature in their own terms ${ }^{9}$, and thus reduce epistemic injustice.

\section{Consequences for practice:}

\footnotetext{
${ }^{8}$ Qualitative methodologies such as ethnographic approaches, accompanied visits and participant observation can enable researchers to gain rich data on the meanings of relational values and provide insights into the experiences and approaches of caring for nature. Combining/linking these with quantitative and spatial methods would enable exploration of distribution and location of caring for nature practices at different spatial scales.

${ }^{9}$ This involves giving more attention to motivational structures and 'moral emotions' [77] of people engaged in nature conservation [78]. Yet this focus has to be connected to the universalist' ideas of justice and human rights, as the two are not contradictory but complementary.
} 
Regarding conservation practice, the fact that certain people care for certain elements of nature will not per se lead to 'more' or 'better' conservation. However, taking a care perspective would help shift the focus from the abstract notion of what people value, which per se does not provide very clear implications as to how nature is to be used or conserved (e.g. wilderness vs managed conservation), to a practice-oriented level of caring for. What someone cares for, how and why, provides a much more tangible entry point as to how an area is to be used or not, what practices are acceptable to different groups etc. So the main benefit of the care concept for conservation practice may lie in asking the right questions rather than providing pro-conservation answers.

Relationships with nature are often not well developed and care might not take place due to a lack of embodied engagement with nature $[79,80]$. One way to enable people to reconnect to nature could be to create or enhance occasions for them to care for specific natural entities (a landscape, an animal/plant). Opportunities to embed concepts and actions associated with care for nature can be sought in everyday life, practices and institutions, such as the Forest School movement which takes learning outside of the classroom and provides opportunities for exploration and to embed caring relationships with nature into everyday school life [81].

\section{Conclusions}

As we have described in this paper, concepts of caring for nature have been developed in different fields, such as indigenous and traditional ideas of human relationships with nature and in modern concepts of environmental ethics and conservation biology. Among recent approaches, feministic environmental philosophy has been the field which has most systematically conceptualised "care for nature", on which we strongly draw here.

We have described care and its relevance to nature conservation here in three major ways, namely a) as a relational and context-sensitive approach to justification of conservation measures, b) as an attitude that is focused on the well-being of (particular) others, and c) as a (variety of) concrete practices rooted in culture, religion or emotion.

When perceived in this way, 'care for nature' is multi-faceted: it is focused on what humans do for nature (and specific natural entities) and at the same time it acknowledges that caring is rooted in the concept of a relational self and is thus a constitutive part of what it means to live a good, really human life. Recognising and promoting this can thus be an important argument for nature conservation, although it will not replace other - utilitarian - arguments. Having said that, we are highly aware of a tension that exists here: if the concept of caring for nature is used strongly as a strategic tool to foster human well-being and nature conservation it may contradict the very idea that we described as underlying most care concepts, namely them being non-instrumental, reciprocal and other regarding in the first place. Using the concept mostly strategically would undermine the credibility of those using it and may thus also compromise the intrinsic motivations of people to care for nature. Avoiding this requires alertness and self-reflection both on the sides of researchers and practitioners. Keeping that in mind, further reflecting on and practising care for nature could indeed inspire and strongly alter the approaches to carrying out research on conservation and the conduct of conservation.

\section{Acknowledgements}

The idea for this paper and a first outline go back to two workshop on "Human well-being and Ecosystem services" which were organized by Kurt Jax, Thomas Potthast, Barbara Muraca and Marion Potschin. They were held on the island of Frauenchiemsee/Germany in March 2015 and in Tübingen in December 2015. We want to thank all the (other) participants for their productive discussions as well as the University of Tübingen for a generous funding from the Exploration Funds Zukunftskonzept. 
We dedicate this paper to the late Felix Rauschmayer. He was among the initiators of a small working group on care, ecosystem services and human-well-being. He really lived an attitude and practice of caring, both for humans and for nature. We will miss his friendliness, openness and brilliant mind.

\section{References}

1. ** Pascual U, Balvanera P, Díaz S, Pataki G, Roth E, Stenseke M, Watson RT, Başak Dessane E, Islar $M$, Kelemen $E$, et al.: Valuing nature's contributions to people: the IPBES approach. Current Opinion in Environmental Sustainability 2017, 26-27:7-16.

Introduces the concept of "nature's contributions to people" as an overarching concept which extends the concept of ecosystem services as a description of human relationships with nature. By including also relational values as another crucial category of values into the IPBES framework it allows for the inclusion of a broader set of world views and value systems.

2. Díaz S, Pascual U, Stenseke M, Martín-López B, Watson RT, Molnár Z, Hill R, Chan KMA, Baste IA, Brauman KA, et al.: Assessing nature's contributions to people. Science 2018, 359:270-272.

3. Eser U, Potthast T: Naturschutzethik. Eine Einführung für die Praxis. Baden-Baden: Nomos; 1999.

4. Jax K, Barton DN, Chan KMA, de Groot R, Doyle U, Eser U, Görg C, Gomez-Baggethun E, Griewald Y, Haber W, et al.: Ecosystem services and ethics. Ecological Economics 2013, 93:260-268.

5. **Chan KMA, Balvanera P, Benessaiah K, Chapman M, Díaz S, Gómez-Baggethun E, Gould RK, Hannahs N, Jax K, Klain SC, et al.: Why Protect Nature? Rethinking Values and the Environment. Proceedings of the National Academy of Sciences of the United States of America 2016, 113:1462-1465.

Discusses a new frame of environmental protection by defining relational values. It suggests that although intrinsic and instrumental values are critical to conservation, thinking only in these terms may miss a fundamental basis of concern for nature.

6. UNESCO. 2015. Cultural landscapes. http://whc.unesco.org/en/culturallandscape/

7. Escobar A:. Territories of difference : Place, movements, life, redes (New ecologies for the twentyfirst century). Durham: Duke University Press; 2008.

8. Descola P: Beyond Nature and Culture. University of Chicago Press;2013.

9. Zimmer A, Cornea N, Véron R: Of parks and politics: the production of socio-nature in a Gujarati town. Local Environment 2017, 22:49-66.

10. Nisbet EK., Zelenski JM., Murphy SA., 2009. The Nature Relatedness Scale: Linking Individuals' Connection With Nature to Environmental Concern and Behavior. Environment and Behavior 2009 41: 715-740.

11. Mayer FS, Frantz CM: The connectedness to nature scale: A measure of individuals' feeling in community with nature. Journal of Environmental Psychology 2004, 24:503-515.

12. Perkins HE:. Measuring love and care for nature. Journal of Environmental Psychology 2010, 30: 455-463.

13. Graeber D: Toward an anthropological theory of value. New York: Palgrave; 2001.

14. Brock K: It's not only wealth that matters-it's peace of mind too: a review of participatory work on poverty and ill-being. www.worldbank.or/poverty/voices/reports. 1999.

15. Sen A: Capability and well-being. In The quality of life. Edited by Nussbaum M, Sen A: Claredon Press; 1993:30-53.

16. Muraca B:. Relational Values: A Whiteheadian Alternative for Environmental Philosophy and Global Environmental Justice. Balkan Journal of Philosophy 2016, 8: 19-38. 
17. Himes, this issue. EVISE manuscript number: COSUST_2017_175

18. Groenhout R: Connected lives: Human nature and an ethics of care (Feminist constructions). Lanham, Md.: Rowman \& Littlefield; 2004.

19. Held. V: Ethics of Care. In The Oxford Handbook of Ethical Theory.Edited by Copp D. Oxford: Oxford University Press 2006: 537-566.

20. West this issue. EVISE manuscript number: COSUST_2018_9

21. Mayseless, O: (2015). The Caring Motivation: An Integrated Theory, Oxford, Oxford University Press; 2015.[21] 18. Nelson JA:. Feminism, ecology and the philosophy of economics. Ecological Economics 1997, 20:155-162.

22. Jochimsen M., Knobloch U: Making the hidden visible: the importance of caring activities and their principles for any economy. Ecological Economics 1997, 20, 107-112.

23. Warren, K:. Ecofeminist Philosophy: A Western Perspective on what it is and why it Matters: Rowman \& Littlefield; 2000.

24. Buch, ED: Anthropology of Aging and Care. Annual Review of Anthropology 2015, 44: 277-293.

25. Tronto, J: Moral Boundaries: A Political Argument for an Ethic of Care. London: Routledge; 1993.

26. Ungerson C: The language of care: crossing the boundaries. In Gender and Caring: Work and Welfare in Britain and Scandinavia, Edited by C. Ungerson C. London: Harvester Wheatsheaf: 1990: 8-33.

27. Gilligan C: In a different voice : Psychological theory and women's development. Cambridge, Mass.: Harvard University Press; 1982.

28. Gruen L. Attending to nature: Empathetic engagement with the more than human world. Ethics \& the Environment 2009, 14:23.

29. Vining J: The connection to other animals and caring for nature. Human Ecology Review 2003, 10:87-99.

30. Geist C., Galatowitsch S: Reciprocal Model for Meeting Ecological and Human Needs in Restoration Projects. Conservation Biology 1999, 13:970-979.

31. Singh,NM: Payments for ecosystem services and the gift paradigm: Sharing the burden and joy of environmental care. Ecological Economics 2015, 117 Issue C: 53-61.

32. Biesecker A, Hofmeister S:. "Focus:(Re) productivity: Sustainable relations both between society and nature and between the genders." Ecological Economics 2010, 69:1703-1711.

33. O'Hara, SU: Sustainability: Social and ecological dimensions. Review of Social Economy 1995 53:529-551.

34. Spangenberg J, Görg C, Thanh Truong D, Tekken V., Bustamante, JV., Settele J: Provision of ecosystem services is determined by human agency, not ecosystem functions. Four case studies. International Journal of Biodiversity Science, Ecosystem Services \& Management 2014, 10: $40-53$.

35. Farrell $\mathrm{KN}$ :. Intellectual mercantilism and franchise equity: A critical study of the ecological political economy of international payments for ecosystem services. Ecological Economics 2014: 102:137-146.

36. Castree N: Social Nature: Theory, Practice and Politics. Wiley-Blackwell; 2001.

37. Muraca B: Re-appropriating the Ecosystem Services concept for a decolonization of 'nature'. In Nature and Experience. Edited by Bannon B. Rowman \& Littlefield, 2016: 143-156.

38. McEwan C, Goodman MK: Place Geography and the Ethics of Care: Introductory Remarks on the Geographies of Ethics, Responsibility and Care. Ethics, Place \& Environment 2010, 13:103-112. 
39. Jackson S, Palmer LR: Reconceptualizing ecosystem services: Possibilities for cultivating and valuing the ethics and practices of care. Progress in Human Geography 2015, 39:122-145.

40. Calestani M, White N, Hendricks, A-J, Scemons D: Religions of native peoples and nursing. In Religion, religious ethics, and nursing. Edited by Fowle, MD. , Reimer-Kirkham S, Sawatzky R, Johnston-Taylor E. New York, U.S.A. : Springer; 2012: 267-294.

41. Comberti C, Thornton TF, Wyllie de Echeverria V, Patterson T: Ecosystem services or services to ecosystems? Valuing cultivation and reciprocal relationships between humans and ecosystems. Global Environmental Change 2015, 34:247-262.

42. *Fox CA, Reo NJ, Turner DA, Cook J, Dituri F, Fessell B, Jenkins J, Johnson A, Rakena TM, Riley C, et al.: "The river is us; the river is in our veins": re-defining river restoration in three Indigenous communities. Sustainability Science 2017, 12:521-533.

Provides an excellent example of how ideas of care for nature have been part of indigenous approaches towards river restoration and how such socio-cultural protocols and spiritual practices are used to the benefits of both humans (and their communities) and nature.

43. Rose D: An indigenous philosophical ecology: Situating the human. Australian Journal of Anthropology 2005, 16:294-305.

44. Sangha KK, Le Brocque A, Costanza R, Cadet-James Y: Ecosystems and indigenous well-being: An integrated framework. Global Ecology and Conservation 2015, 4:197-206.

45. Ogungbemi S:. An African Perspective on the Environmental Crisis." In Environmental Ethics: Readings in Theory and Application. Edited by: Pojman, L. Belmont, CA: Wadsworth Publishing Company; 1997

46. Ojomo PA: Environmental ethics: An African understanding. African Journal of Environmental Science and Technology 2011, 5, 572-578.

47. Grese RE, Kaplan R,Ryan RL, Buxton J:. Psychological benefits of volunteering in stewardship programs. In Restoring nature. Perspectives from the social sciences and humanities. Edited by Gobster PH, Hull RB: 265-280. Island Press, 2000.

48. Piliavin JA, Siegl E: Health benefits of volunteering in the Wisconsin Longitudinal Study. Journal of Health and Social Behavior 2007, 48: 450-464.

49. Husk K, Lovell R, Cooper C, Stahl-Timmins W, Garside R.: Participation in environmental enhancement and conservation activities for health and well-being in adults: a review of quantitative and qualitative evidence. Cochrane Database of Systematic Reviews 2016, Issue 5. Art. No.: CD010351. DOI: 10.1002/14651858.CD010351.pub2.

50. De Jonge C, Whiteman G: Arne Naess (1912-2009). Oxford Handbook of Process Philosophy and Organization Studies. Edited by.Helin J, Hernes T, Hjorth D, Holt, R. Oxford University Press; 2014:432-451.

51. Leopold A: A Sand County almanac and sketches here and there. New York: Oxford University Press; 1949.

52. Moore KD: The pine island paradox. Making connections in a disconnected world. Milkweed Editions; 2004.

53. Norlock KJ: Building receptivity: Leopold's Land Ethic and and critical feminist interpretation. Journal for the Study of Religion, Nature and Culture 2011, 5:491-509.

54. Rolston $\mathrm{HI}$ : Caring for nature: What science and economics can't teach us but religion can. Environmental Values 2006, 15:307-313.

55. Bakken PW: Stewardship. In Encyclopedia of Environmental Ethics and Philosophy. Edited by Callicott JB, Frodeman R: MacMillan Reference USA; 2009:Vol. 2, 282-284. 
56. * Bennett NJ, Whitty TS, Finkbeiner E, Pittman J, Bassett H, Gelcich S, Allison EH: Environmental stewardship: A conceptual review and analytical framework. Environmental Management 2018, 61:597-614.

Reviews the various ideas connected to the concept of environmental stewardships and tries to set up an integrative framework for local environmental stewardship, focusing on actors, capacities, and motivations.

57. Chapin FS, Carpenter SR, Kofinas GP, Folke C, Abel N, Clark WC, Olsson P, Smith DMS, Walker B, Young $O R$, et al.: Ecosystem stewardship: sustainability strategies for a rapidly changing planet. Trends in Ecology \& Evolution 2009, 25:241-249.

58. Rozzi R: Earth Stewardship and the biocultural ethic: Latin American perspectives. In Earth stewardship. Linking ecology and ethics in theory and practice. Edited by Rozzi R, Chapin FSI, Callicott JB, Pickett STA, Power ME, Armesto JJ, May RH: Springer; 2015:87-112.

59. Cafaro P, Sandler R.L. (eds.): Environmental virtue ethics. Rowman \& Littlefield Publishers; 2005

60. Lenzi D: Relativism, ambiguity and the environmental virtues. Environmental Values 2017, 26:91-109.

61. De Groot, this issue. EVISE manuscript number: COSUST_2017_165

62. Thomas A: Virtue ethics and an ethics of care: complementary or in conflict? Eidos 2011, 14:132-151.

63. Smith DM: How far should we care? On the spatial scope of beneficence. Progress in Human Geography 1998, 22:15-38.

64. Klaver I, Keulartz J, van den Belt H, Gremmen B: Born to be wild: a pluralistic ethics concerning introduced large herbivores in the Netherlands. Environmental Ethics 2002, 24:3-21.

65.Horkheimer, Max (1947): Eclipse of Reason. New York: Oxford University Press.

66. Nussbaum, M: Upheavals of Thought: The Intelligence of Emotions. Cambridge, Cambridge University Press; 2001.

67. Haines-Young R, Potschin M: The links between biodiversity, ecosystem services and human well-being. In Ecosystem ecology: a new synthesis. Edited by Raffaelli DG, Frid CL: Cambridge University Press; 2010:110-139.

68. UNEP: IPBES/4/INF/1: preliminary guide regarding diverse conceptualization of multiple values of nature and its benefits, including biodiversity and ecosystem functions and services (deliverable $3(d))$. Report of the Fourth Session of the Plenary of the Intergovernmental Science-Policy Platform on Biodiversity and Ecosystem Services: http://www.ipbes.net/sites/default/ files/downloads/IPBES-4-INF-13_EN.pdf ; 2015

69. Martínez-Alier J, Munda G, O'Neill J: Weak comparability of values as a foundation for ecological economics. Ecological Economics 1998, 26:277-286.

70. Gómez-Baggethun E., Martín-López B.: Ecological economics perspectives on ecosystem services valuation. In Handbook of Ecological Economics. Edited by Martínez-Alier J., Muradian, R. Cheltenham: Edward Elgar; 2015.

71. Jacobs S, Dendoncker N, Martín-López B, Barton DN, Gomez-Baggethun E, Boeraeve F, McGrath FL, Vierikko K, Geneletti D, Sevecke Katharina J, et al.: A new valuation school: Integrating diverse values of nature in resource and land use decisions. Ecosystem Services 2016, 22, Part B:213-220.

72. Rauschmayer F., Wittmer H.: Evaluating deliberative and analytical methods for the resolution of environmental conflicts. Land Use Policy, 2006, 23:108-122. 
73. O'Brien L. Mazarno M., White R.; Participatory interdisciplinarity: towards the integration of disciplinary diversity with stakeholder engagement for new models of knowledge production. Science and Public Policy, 2013, 40:51-61.

74. Irvine K, O'Brien L, Ravenscroft N, Fazey I, Reed,M, Kenter J: Ecosystem services and the idea of shared values. Ecosystem Services 2016, 16:184-193.

75. **Kenter J, Byrce R, Christie M, Cooper N, Hockley N, Irvine K, Fazey I, O’Brien L, Orchard-Webb J, Ravenscroft N, et al. Shared values and deliberative valuation: Future directions. Ecosystem Services 2016, 16, 358-371.

Constitutes a synthesis of 15 papers comprising a Special Issue on shared, plural and cultural values. Emphasises the importance of shared, plural and cultural values of ecosystems in contrast to the normal focus on individual values and preferences.

76. Edwards D, Collins T, Goto R: (). An arts-led dialogue to elicit shared, plural and cultural values of ecosystems. Ecosystem Services 2016, 16, 319-328.

77. Plumwood V:. Feminism and the mastery of nature. London/New York: Routledge; 1993.

78. Admiraal JF, Van Den Born RJG, Beringer A, Bonaiuto F, Cicero L, Hiedanpää J, Knights P, Knippenberg LWJ, Molinario E, Musters CJM, et al.: Motivations for committed nature conservation action in Europe. Environmental Conservation 2017, 44:148-157.

79. Louv R: Last child in the woods: saving our children from nature deficit-disorder. Algonquin Books, New York; 2005.

80. Chawla L: Growing up green: becoming an agent of care for the natural world. The Journal of Developmental Processes 2009, 4:6-23.

81. O'Brien L: Learning outdoors: the Forest School approach. Education 3-13 2009, 37:45-60. 